\title{
Bacteriostatic and bactericidal activities of Acalypha indica $L$. plant leave extracts on bacteria shigella disenteriae type 1 in vitro
}

Received 15 September, 2021

Abdul Majid*1 and

Frans Salesman ${ }^{2}$

${ }^{1}$ Lecturer of Pharmacy

Faculty at Citra Bangsa

University East Nusa

Tenggara Indonesia.

${ }^{2}$ Professor in Public Health at

Public Health Faculty at Citra

Bangsa University, East Nusa

Tenggara Indonesia.

*Corresponding Author Email:

abdul311268@gmail.com

Tel. : +6281338886536
Revised 28 October, 2021

Accepted 4 November, 2021

Published 22 November, 2021

This study aimed to analyze the bacteriostatic and bactericidal activity of Acalypha indica $L$. extract against Shigella dysenteriae type 1 bacteria in vitro. This research is a laboratory experimental study consisting of six concentration treatments, namely: $(\mathrm{K}=0 / \mathrm{ml}, \mathrm{P} 1=100 / \mathrm{ml}, \mathrm{P} 2=200 / \mathrm{ml}, \mathrm{P} 3=400 / \mathrm{ml}, \mathrm{P} 4=$ $800 / \mathrm{ml}, \mathrm{P} 5=1600 \mathrm{mg} / \mathrm{ml}$ ), and five replications each. The results showed that the herbal extract of Acalypha indica L. was bacteriostatic (inhibiting) at a concentration of $400 \mathrm{mg} / \mathrm{mm}$, and bactericidal (killing) the bacteria Shigella dysenteriae type 1 , which was tested in vitro at a concentration of at least 800 $\mathrm{mg} / \mathrm{ml}$. It is necessary to study the effect of Acalypha indica L. herbal extract from Timor in the serum of Rattus norwegicus against bacteria that cause bloody diarrhea (EHEC 0157:H7, and Shigella dysenteriae type 1), MRSA bacteria, and other pathogenic bacteria.

Keywords: Extract, Acalypha Indica L, bacteriostatic, Shigella dysenteriae Type -1

\section{INTRODUCTION}

Several human diseases, including malaria, diarrhoea, and typhus, can be treated with fresh herbs from medicinal plants. The benefits of using traditional medicine include fewer side effects, easy access to raw materials, and a low cost. Traditional medicine is preferred by Indonesians who live in rural areas because modern medicine is difficult to access. Acalypha indica L., also known as the cat-cat plant, is a weed that is commonly found growing in the wild.

Acaypha indica L. is an annual herb from the Euphorbiaceae tribe, often found in habitats that are exposed to direct sunlight throughout the day or never exposed to the sun. From these varied habitats, Acalypha indica $L$. can be found with varied morphology. This plant grows wild in Indonesia, grows anywhere, on roadsides, grass fields, yards, between rocks, and on hillsides (Madjid and Nikmah, 2017). The secondary metabolite content of the plant Acalypha indica $L$ which is efficacious include alkaloids, flavonoids, catachol, phenolic compounds, steroids, and saponins (Madjid and Nikmah, 2020).Some of the properties that have been scientifically proven about the effectiveness of antioxidants, anticancer, antiviral, antidiabetic, and antifungal (Nikmah et al., 2009). The Acalypha plant has been shown to have wide uses in various countries and is reported to have diuretic, laxative, anthelmintic properties, as well as being used for bronchitis, asthma, pneumonia, scurvy, and other cutaneous diseases (Hamid and Ramadhania, 2017).

Studies on the antibacterial activity of 4 different extracts, namely hexane, chloroform, ethyl acetate, and methanol from the leaves of Acalypha indica L. have the ability to fight Gram-positive bacteria such as Staphylococcus aureus, Staphylococcus epidermidis, Bacilus cereus, Streptococcus faecalis and Gram-negative bacteria such as Klebsiella pneumoniae, Escherichia coli, 


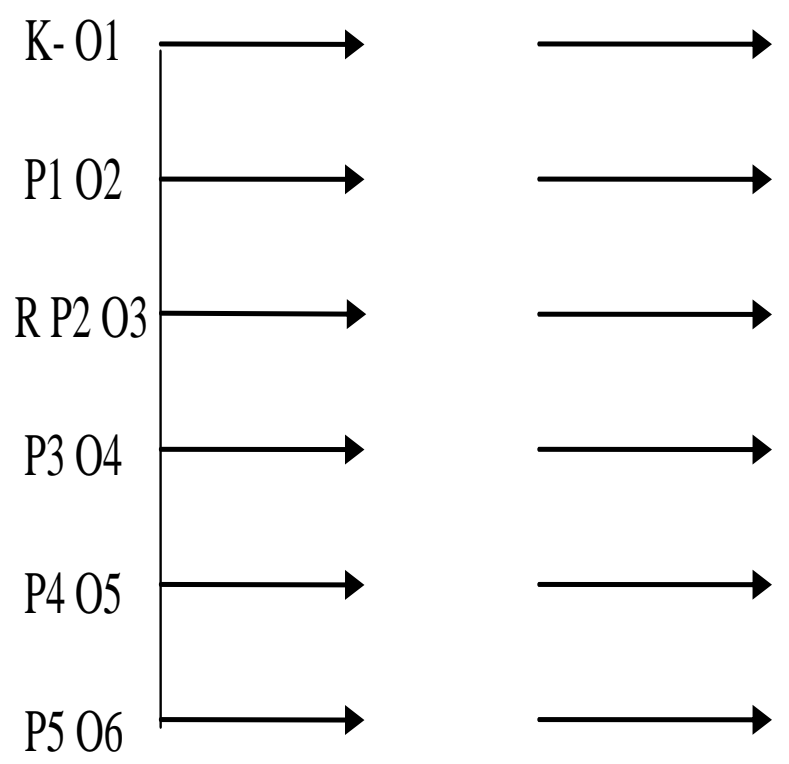

Figure 1. Research Design Chart

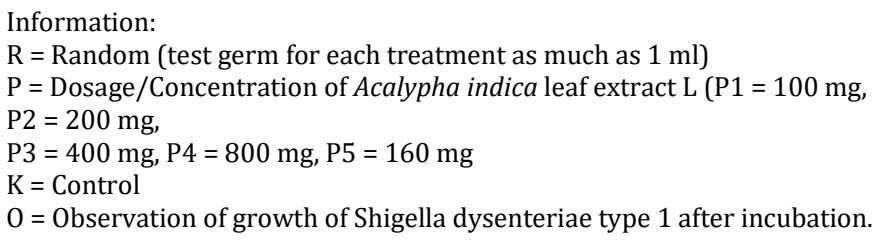

Proteus vulgaris, Pseudomonas aeruginosa. All extracts inhibited Gram Positive antibacterial activity with a minimum inhibitory concentration (MIC) of 0.156-2.5 $\mathrm{mg} / \mathrm{mL}$. Meanwhile, only Gram-negative bacteria are susceptible to Pseudomonas aeruginosa (Hamid and Ramadhania, 2017). In addition to acalyphine compounds, this plant is known to contain polyphenolic compounds, flavonoids, tannins, and essential oils that are beneficial to health. Plants containing flavonoid compounds have been shown to have activity (Rajaselvam et al., 2012).

The cat and mouse plant empirically has been utilized by the community, especially in rural areas in East Nusa Tenggara-Indonesia. All parts of this plant can be used as medicine in fresh or dried form, for the treatment of bacillary dysentery, amoebic dysentery, diarrhea, bleeding such as defecation, blood urine, vomiting blood, nosebleeds, and many other benefits of this plant1. Based on the results of the study, it was found that the juice from the leaves of the Acalypha indica L. plant had antibacterial potential, namely bacteriostatic (inhibiting) the growth of Salmonella pullorum bacteria isolated from calcareous diarrhea chicken feces in vitro at a concentration of $60 \%$. Another study found the root of the earring plant (Acalypha indica $L$.) efficacious as a laxative. An infusion or decoction is taken to treat asthma, intestinal worms,

Based on the two research findings above, it is necessary to test the antibacterial activity of Acalypha indica L plant leaf extract against the growth of Shigella dysenteriae type1. Shigella dysentriae is a gram-negative bacterium in the Enterobactericeae family that can cause (Armansyah et al., 2010; One Hope, 2020). This bacterium is one of the bacteria that causes infections in the digestive tract, especially in children. Dysentery caused by bacteria or shigellosis is caused by bacteria of the genus Shigella. Antimicrobial resistance of Shigella strains is associated with general antimicrobial use in the population (Monica et al., 2020; Mindasari, 2017).

Shigella sp. bacteria, where the feces are visually mixed with blood or blood spots. When compared with "water diarrhea" generally "bloody diarrhea" lasts longer, has more complications and causes a higher mortality rate (Sulastri, 2010). The most common etiology is Shigella disenteriae type 1 bacteria with a pathological mechanism producing cytotoxins and is invasive so that it is more infectious than others with more severe clinical symptoms (Rusli, 2010; Baron et al., 1994).

This study tested the antibacterial activity of Acalypha indica $L$. leaf extract against the growth of Shigella disenteriae type 1 in vitro. The aim was to obtain a minimal bacteriostatic dose/concentration and a minimal bactericidal concentration from the leaf extract of the Acalypha indica L. plant against the growth of Shigella dysenteriae subtype 1 bacteria in vitro.

\section{METHODS AND MATERIALS}

\section{Research design}

The method used is experimental laboratory using Completely Randomized Design with The Post Test - Only Control Group Design pattern. The treatments consisted of six concentrations $(\mathrm{K}=0 \mathrm{mg} / \mathrm{ml}, \mathrm{P} 1=100 \mathrm{mg} / \mathrm{ml}, \mathrm{P} 2=$ $200 \mathrm{mg} / \mathrm{ml}, \mathrm{P} 3=400 \mathrm{mg} / \mathrm{ml}, \mathrm{P} 4=800 \mathrm{mg} / \mathrm{mL}, \mathrm{P} 5=1600$ $\mathrm{mg} / \mathrm{ml}$ water), and each four replications.

The design refers to the following modifications(Figure 1).

This research design was chosen with the assumption that each unit in the population is homogeneous, meaning that all characteristics between population units are the same, so the initial measurement is not carried out because it is considered the same for all groups originating from one population.

\section{Research Sample}

The research sample used was an extract from the Acalypha indica $L$., Shigella dysenteriae type 1 herb which was to be obtained from the lab. Gastroenteritis TDC Unair Surabaya. Then the bacteria were diluted with a population density of $1.5 \times 108 \mathrm{CFU} / \mathrm{ml}$ or 150 million cells/ml of medium after being incubated for 24 hours at $37^{\circ} \mathrm{C}$, which was comparable to the turbidity level of the standard $\mathrm{BaSO} 4$ 0.5/McFarland Standard 0.5 (Rusli, 2010). Samples were taken at simple random randomness. 


\section{Variable observations}

The observed variables include the dose/concentration value which is calculated based on the Viable count. S.

dysenteriae type 1 growing on agar media.

The method used was experimental laboratory, the treatment consisted of six concentrations $(\mathrm{K}=0 / \mathrm{ml}, \mathrm{P} 1=$ $100 / \mathrm{ml}, \mathrm{P} 2=200 / \mathrm{ml}, \mathrm{P} 3=400 / \mathrm{ml}, \mathrm{P} 4=800 / \mathrm{mL}, \mathrm{P} 5=$ $1600 \mathrm{mg} / \mathrm{ml}$ water) , and five replications each.

\section{Tools and Materials}

\section{Research Tools}

In this study using several kinds of instruments. among others:

- For extract: Grinding machine, a set of Sokhlet extractor, vacuum evaporator, water bath, Erlenmeyer tube, blender. Autoclave: Prior to research, all materials and certain equipment must be sterilized by autoclaving.

- Oven: To sterilize glassware before use.

- Incubator: Used because the growth process is regulated at a temperature suitable for the growth needs of the test bacteria.

- Petri dish $9 \mathrm{~cm}$ : As a medium for the growth of test bacteria.

- Colony counter: Used to count the number of live bacteria.

- Test tubes and racks: Used to make suspensions of test bacteria.

- Pipettes and micropipettes: Used to measure the volume of the suspension of the test bacteria, the concentration of the extract and ethanol.

- Analytical balance: Used to measure the weight of a sample .

- Erlemeyer: Used to place materials in the manufacture of the medium.

- Ose needle: Used to transfer test bacteria and is used for suspension and growing test bacteria.

- Beaker (pirex): Used in making the medium prior to sterilization.

- Vortex: Used in the process of making the medium to be homogeneous.

- Shonde: Used to add extract to Rattus norwegicus.

- $5 \mathrm{ml}$ disposable syringe: Used to collect Rattus norwegicus blood.

\section{Research Materials}

The materials used in this study are:

Leaves of Acalypha indica $L$.

Ethanol $96 \%$

methanol $96 \%$.

Dimethyl Sulfoxide (DMSO)

Barium Sulfate $\left(\mathrm{BaSO}_{4}\right)$ and $\mathrm{NaCl}$.

Filter paper

Medium: TSB, BHI, NA, blood agar

$96 \%$ alcohol.
Cotton, tissue, aquades, spiritus

Bacteria: Shigella dysenteriae type 1

\section{Data Collection Procedure}

\section{Extract Making}

The preparation of Acalypha indica L. leaf extract, the procedure refers to the 2006 Harbone, namely: Acalypha indica $L$. leaves are dried on a clothesline without direct sunlight. After drying, it is made into a fine powder using a grinding machine. $2 \mathrm{~kg}$ fine powder was immersed in $96 \%$ ethanol solvent for $4 \times 24$ hours. Every 24 hours filtered and then added ethanol. The filtrate was collected in a sterile Erlenmeyer tube. 12 liters of filtrate was evaporated with a vacuum evaporator to obtain a thick extract. The viscous extract was dried by freeze dryer (Madjid and Nikmah, 2017).

\section{Test Bacterial Culture}

Cultures of test bacteria were propagated on nutrient agar medium. After planting, they were incubated at $37 \mathrm{oC}$ for 24 hours.

\section{Making a Test Bacteria Suspension}

From the test bacteria cultures, 4-5 colonies were taken, then suspended and put in a tube containing $5 \mathrm{ml}$ of $0.85 \%$ sodium chloride $(\mathrm{NaCl})$ solution. After that, the turbidity of $\mathrm{NaCl}$ containing the test bacteria was adjusted to the standard turbidity of barium sulfate (BaSO4) 0.5 (Mc.Farland 0.5). After the turbidity is appropriate, the test bacteria in the liquid medium can be planted on the examination medium (Madjid and Nikmah, 2020).

\section{Testing the Antibacterial Activity of Extracts of Acalypha indica $L$.}

To determine the activity of leaf extract Acalypha indica L. against the bacterium Shigella dysenteriae type 1 in vitro, carried out using the tube dilution method referring to the steps (Madjid and Nikmah, 2020). The steps of the tube dilution method are as follows:

a. Extract Acalypha indica L. as much as $800 \mathrm{mg}$ was dissolved in $16 \mathrm{ml}$ of $0.2 \%$ ethanol solvent, and $4 \mathrm{ml}$ of DMSO.

b. It was diluted with broth (MH-broth), to obtain a series of sample concentrations of $800 \mathrm{mg} / \mathrm{ml}, 400 \mathrm{mg} / \mathrm{ml}$, $200 \mathrm{mg} / \mathrm{ml}, 100 \mathrm{mg} / \mathrm{ml}, 50 \mathrm{mg} / \mathrm{ml}$, and a control compound of $0 \mathrm{mg} / \mathrm{ml}$.

c. Each concentration of the extract was taken $1 \mathrm{ml}$ and added $1 \mathrm{ml}$ of suspension of the test bacteria aged 24 hours each, so that each concentration contained as much as $150 \mathrm{million} / \mathrm{ml}$ of test bacteria $(1.5 \times 108 \mathrm{CFU} / \mathrm{ml})$.

d. Then it was vortexed and then incubated for 24 hours, at $37^{\circ} \mathrm{C}$.

e. After incubation, each dilution was carried out. 
Table 1. Data of Research Results Number of Bacterial Colonies of Shigella dysenteriae type 1 (Viable Count) and $\mathrm{CFU} / \mathrm{ml}$ value. After Exposure Acalypha indica L. herbal extract extract with the Drop Method

\begin{tabular}{|c|c|c|c|c|c|c|c|c|}
\hline Bacteria & Reply & $\mathbf{K}$ & P1 & P2 & P3 & P4 & P5 & P6 \\
\hline Shigella & 1 & TBUD & TBUD & TBUD & TBUD & $253(2.5 \times 104)$ & 0 & 0 \\
\hline dysenteriae & 2 & TBUD & TBUD & TBUD & TBUD & $238(2.4 \times 104)$ & 0 & 0 \\
\hline \multirow[t]{4}{*}{ type 1} & 3 & TBUD & TBUD & TBUD & TBUD & $192(2.9 \times 104)$ & 0 & 0 \\
\hline & 4 & TBUD & TBUD & TBUD & TBUD & $186(1.9 \times 104)$ & 0 & 0 \\
\hline & 5 & TBUD & TBUD & TBUD & TBUD & $219(2.2 \times 104)$ & 0 & 0 \\
\hline & Mean & - & - & - & - & $261(2.6 \times 104)$ & 0 & 0 \\
\hline
\end{tabular}

Information: TBUD = Too Many To Count

Zero $(0)=$ Bacteria Not Growing

f. The 10-2 dilution was planted in $1 \mathrm{ml}$ on agar media by the drop method.

g. Allowed to dry at room temperature, then incubated for 24 hours, at $37^{\circ} \mathrm{C}$.

h. After incubation, the number of Shigella dysenteriae type 1 colonies was counted.

i. At the lowest concentration showing bacteriostatic or bactericidal activity, then compared with the control.

\section{RESULTS AND DISCUSSION}

\section{Research Results}

Research result antibacterial activity of Acalypha indica $L$ herbal extract. against Shigella dysenteriae type 1 bacteria in vitro, the data were obtained by calculating the number of bacterial colonies that grew (viable count). The results of observing the number of colonies of Shigella dysenteriae type 1 bacteria growing (viable count) on agar media as an effect of the antibacterial activity of Acalypha indica $L$. herbal extract in vitro, can be seen in Table 1:

Based on the data in Table 1 shows that the treatment with concentrations of $0 \mathrm{mg} / \mathrm{ml}(\mathrm{K}), 50 \mathrm{mg} / \mathrm{ml}(\mathrm{P} 1), 100 \mathrm{mg} / \mathrm{ml}(\mathrm{P} 2)$, and $200 \mathrm{mg} / \mathrm{ml} \mathrm{(P3)} \mathrm{the} \mathrm{number} \mathrm{of} \mathrm{bacterial} \mathrm{colonies} \mathrm{was} \mathrm{too}$ much to count. Treatment with a concentration of $400 \mathrm{mg} / \mathrm{ml}$ (P4) showed that the number of colonies could be counted with an average value of 216 colonies. Treatments with concentrations of $800 \mathrm{mg} / \mathrm{ml}$ (P5) and $1600 \mathrm{mg}$ (P5) showed the number of colonies was 0 (not growing).

Based on the data in Table 1 that the treatment with the concentration of Acalypha indica L. herbal extract $50 \mathrm{mg} / \mathrm{ml}$ to $200 \mathrm{mg} / \mathrm{ml}$ the number of bacterial colonies was too much to count (TBUD) this means that it does not have antibacterial activity against the type Shigella dysenteriae bacteria tested internally. vitro. Treatment with a concentration of $400 \mathrm{mg} / \mathrm{ml}$ the average number of Shigella dysenteriae type 1 bacteria that grew was 261 colonies (2.6x104) $\mathrm{CFU} / \mathrm{ml}$, this means that it has antibacterial activity that is bacteriostatic in nature, namely inhibiting the growth of Shigella dysenteriae type bacteria tested in vitro. . Treatment with concentrations of 800 , and 1600 $\mathrm{mg} / \mathrm{ml}$ did not show any bacterial growth, this means that it has bactericidal antibacterial activity, which kills the bacteria Shigella dysenteriae type 1 which was tested in vitro.

Based on the description of the research results above, it shows that The herbal extract of Acalypha indica L. has antibacterial activity (bacteriostatic and bactericidal) namely inhibiting at a concentration of $400 \mathrm{mg} / \mathrm{ml}$, and killing Shigella dysenteriae type 1 which was tested in vitro at a concentration of $800 \mathrm{mg} / \mathrm{ml}$.

\section{DISCUSSION}

Observation results show that The herbal extract of Acalypha indica L. which was taken in the Kayu Putih village, Kupang City has antibacterial activity (bactericidal) or kills the bacteria Shigella dysenteriae type 1 which was tested in vitro at a concentration of $800 \mathrm{mg} / \mathrm{ml}$. This can happen because the higher the dose or concentration of Acalypha indica $L$. extract, the more active ingredients that function as antibacterial. In relation to the results of this study, Jawetz et al. in 2001 explained that among several factors that influence in vitro antibacterial activity that greatly affect the test results, among others: environmental $\mathrm{pH}$, media components, stability of antimicrobial materials, inoculum size, incubation time, and activity of microorganism metabolites (Jawetz and Adelberg, 2001). The secondary metabolite content of the plant Acalypha indica $L$ which is efficacious include alkaloids (Baron et al., 1994; Jawetz and Adelberg, 2001).

Schlegel (1994) suggested that the ability of an antimicrobial agent to destroy the viability of an organism depends on the concentration of the antibacterial agent. This means that the amount of antibacterial material in a bacterial environment will determine the life of the bacteria (Schlegel, 1994). In addition to the concentration factor, the type of antimicrobial material also determines the ability to inhibit bacterial growth. The results of the study by Nikmah et al. (2009) showed that Extracts of leaves, flowers, stems, roots of the plant Acalypha indica $L$. contain antibacterial compounds, namely Nikmah et al., 2009): (1) Sapsonic compounds and polyphenols are found in extracts of leaves, flowers, stems, roots. (2) Flavonoid compounds are only found in flower extracts. (3) Tannin compounds were not present in all organs of the herbaceous plant Acalypha indica L. It was found that the 
plant extract of Acalypha indica L. contained antibacterial compounds, namely saponins, polyphenols, and flavonoids.

The results of this study indicate that Acalypha indica $L$. herbal extract from Kupang, East Nusa Tenggara has antibacterial activity that is lethal bactericidal. The bacteria causing Shigella dysenteriae type 1 were tested in vitro at a concentration of $800 \mathrm{mg} / \mathrm{ml}$. This happens because the herbal extract of Acalypha indica L. from Kupang, East Nusa Tenggara has antibacterial compounds in the form of saponins, polyphenols, and flavonoids.

Siswandono et al. (2010) stated that to give a biological effect, a drug in its active form must interact with the receptor or site of action or target cells with a sufficiently high concentration, so that with the covalent bond an antibacterial mechanism of action can occur in the form of saponins or polyphenols, and/or flavonoids. with the transpeptidase enzyme (enzyme plays a role in cell wall synthesis), although it must be in a high enough concentration indicated by the attack of the serine hydroxyl group of the transpeptidase enzyme on the positively charged carbonyl active group on the diterpenoid ring of lactones, antibacterial compounds in the form of saponins, polyphenols, and flavonoids, so that peptidoglycan synthesis inhibition, as shown by the mechanism of action of lactam antibiotics Soetanto et al. (2010); Siswandono and Soekardjo (2010). As a result, the cell wall becomes weak, and due to turgor pressure from within, the cell wall will rupture so that the bacteria die.

\section{Conclusion}

This study concluded that the antibacterial activity of plant extracts of Acalypha indica $L$. was bacteriostatic and bactericidal against Shygella dysenteriae type 1:

1. The plant extract of Acalypha indica $L$. is bacteriostatic (inhibits) against Shygella dysenteriae type 1 at a concentration of $400 \mathrm{mg} / \mathrm{ml}$.

2. The plant extract of Acalypha indica L. was bactericidal against Shygella dysenteriae type 1 at concentrations of $800 \mathrm{mg} / \mathrm{ml}$ and $1600 \mathrm{mg} / \mathrm{ml}$.

3. Acalypha indica $L$ leaf extract is bacteriostatic at a minimum dose of $400 \mathrm{mg}$ and a minimum bactericidal 800 mg against Shygella dysenteriae type 1 .

\section{Recommendations}

The results of this study are preliminary research, for that in the future it is recommended; (1) Conducted research on the effect of Acalypha indica L. herbal extract from Timor in Rattus norwegicus serum against bacteria that cause bloody diarrhea (EHEC 0157:H7, and Shigella dysenteriae type 1), MRSA bacteria, and other pathogenic bacteria; and (2) Conducting research using other medicinal plants, to find and enrich alternative drugs against bloody diarrhea infection.

\section{Acknowledgment}

The award was presented to the Chancellor of the University of Citra Bangsa Kupang and the Head of the Pharmacy Study Program who had provided research funds and a laboratory for testing research materials. Also to research assistants, namely the Pharmacy Study Program Students who helped this research to completion.

\section{Conflict of Interest}

There is no conflict of interest in the process or results of the research because it does not use human trials or violates the norms and values that exist in the community that uses research results

\section{REFERENCES}

Armansyah TR, Sutriana A, Aliza D, Vanda H, Rahmi H (2010). Hepatoprotective Activity of Ethanol Extract of Acalypha indica L. Leaves in White Rats (Rattus Novergicus) Induced by Paracetamol. Scientific Journal of Animal Sciences May, 2010, Vol. XIII, No. 6;

Baron EJ, Linsey JR, Finegold SM (1994). Baily \& Scott's Diagnostic Microbiology 9th edition, Philadelphia: Mosbyyear book, Inc;

Berghe DA, Vlientinck AJ (1991). Screening methods for Antibacterial and antiviral Agent From higher Plant. Methods in Plant Biochemistry, Vol. 6, London, Harchourt Brace Javanovich Publisher;

Diterpenoids from A. paniculata Nees. Against Cytotoxicity Function of T-Cytotoxic Lymphocytes (CD8+) in Mice.Thesis. Airlangga University, Surabaya.

Fanggi JN (2019). Second Most Common Diarrhea Disease in East Nusa Tenggara: Change Habits to Overcome Diarrhea, Indonesian Guard, https://gardaindonesia.id/2019/08/24/diarrhea-

disease-terbanyak-kedua-di-ntt-ubah-kecepatan-atasidiarrhea/, accessed August 3, 2020, 11:34 am;

Hamid SK, Ramadhania ZM (2017). Biological Activity of Cat and Mouse Plant (Acalypha indica L). JournalPharmacology, Volume 15 Number 3;

Jawetz, M, \& Adelberg's (2001). Medical Microbiology (Translation. Department of Microbiology, Faculty of Medicine, Airlangga University, Surabaya). Jakarta. Salemba;

Madjid A, Nikmah (2017). Antibacterial Potential of Acalypha indica L. Leaf Juice Against Salmonella pullorum Bacteria In Vitro. Proceedings of the 2nd National Biological Science and Education Seminar. Kupang, 23 September 2017;

Madjid A, Nikmah (2020). Identification of Antibacterial Compounds in Root Extracts of Acalypha indica L. Herbs from Kupang City.CHM-K Applied Scientifics Journal, Volume 3 Number 3, September 2020, eISSN : 2622-0490, pISSN : 2622-6049; 
Mindasari A (2017). Provision of Cambodian Flower (PlumeriarubraL.) Ethanol Extract to the Growth of Shigella dysenteriae Bacteria with the Well Diffusion Method. Hangtuah Medical Journal. Volume 15, number 1; 2017, pages 1-9;

Monica RM, Achadiyani, Astrid F, Michael K, Tumbol V (2020). Antibacterial Power of Sabrang Onion (Eleutherine americana) Ethanol Extract Against Shigella dysentriae and Salmonella enteritidis. Indonesian J. Pharma. Sci., April 2020, p. 109-117 ISSN 1693-1831, EISSN 2614-6495, Vol.18, No.1;

Nikmah AS, Ardan, Majid A (2009). Identification of Antibacterial Compounds from Herbal Extracts of Acalypha indica L. Competitive Grant Research Report. Nusa Cendana University. Kupang.

One Hope (2020). Ating - Earrings Alias Cat Fierce, Wood Shrub Benefits. Flora \& Faunahttp://www.satuharapan.com/readdetail/read/anting-anting-alias-kucing-galakperdu-kaya-hasil, Accessed May 17, 2020, at 15.28 WIT;

Rajaselvam J, Benila SJM, Meena R (2012). A Study of Antimicrobial Activity of Acalypha indica against Selected Microbial Species. International J. Pharma Sciences and Research. Vol. 3, No. 9;

Rusli S (2010). Management of Bloody Diarrhea in Adult Patients. Literature review, Indonesian Infectious Disease Magazine, No. 1, Jakarta;
Schlegel HG (1994). General Microbiology. (with assistance from Karim Schmidt; Translator Tedjo Baskoro; Editor Joke R. Wattimena. Gadjah Mada University. Jogyakarta;

Siswandono and Soekardjo B (2010). Medical Chemistry. Surabaya: Airlangga University Press, Surabaya;

Soekardjo B, Harjono S, Robby S (2010). Relationship of Drug Activity Structure, in: Medicinal Chemistry. Airlangga University Press, Surabaya.

Soetanto T, Sondang MS, Sukiman R (2010). Pattern of microbial sensitivity to antibiotics commonly used in cases of acute diarrhea. Original Article Indonesian Infectious Diseases Magazine, Jakarta;

Sulastri S (2010). Management of Bloody Diarrhea in Outpatients. Literature Review, Indonesian Infectious Disease Magazine No.1, Jakarta;

Widyawaruyanti A (1999). Imunomodulator activity of diterpenoid compound of Andrographis paniculata Nees on the function of T-lymphocyte cytotoxicity (CD +8) mice. Thesis. Universitas Airlangga. (Article in Indonesian). 